\title{
Movement of Phytophthora spp. in Maryland's Nursery Trade
}

\author{
J. C. Bienapfl and Y. Balci, Plant Science \& Landscape Architecture, University of Maryland, College Park 20742
}

\begin{abstract}
Bienapfl, J. C., and Balci, Y. 2014. Movement of Phytophthora spp. in Maryland's nursery trade. Plant Dis. 98:134-144.

Phytophthora spp. cause major losses in the nursery industry worldwide. However, a clear demonstration of the route of movement has not been previously shown. A survey of 10 Maryland nurseries was conducted over a 3-year period to investigate the presence of Phytophthora spp. on newly arrived plants, mainly from West Coast suppliers. Local nursery plants, irrigation water, and potting media were also sampled for Phytophthora spp. Isolates were identified using a combination of morphological characteristics and DNA sequencing. Species identified included Phytophthora cactorum, $P$. cambivora, $P$. cinnamomi, $P$. citrophthora, $P$. drechsleri, $P$. elongata, $P$. gonapodyides, P. hydropathica, P. irrigata, P. lacustris, P. multivora, P. nicoti-

anae, $P$. pini, $P$. plurivora, and $P$. syringae. $P$. taxon pgchlamydo was also isolated from irrigation water. Eight of the abovementioned Phytophthora spp. were isolated in association with incoming material, indicating that the movement of these pathogens continues to occur. Asymptomatic plant material was the main route of introduction of Phytophthora spp. to Maryland nurseries. Results also indicated that several Phytophthora spp. could be found in Maryland nurseries in association with infested potting media of asymptomatic plants. Although $P$. ramorum was not detected, our surveys underscore the significance of nursery practices that allow introductions of these significant plant pathogens to new geographic locations.
\end{abstract}

The most recent assessment of the wholesale value of nursery crops in the United States was estimated at \$4.65 billion in 2006 (United States Department of Agriculture [USDA] National Agricultural Statistics Service). Nursery crops consist of high-value plant species with intensive labor inputs and low tolerance for damage to plants. Therefore, economic losses can be severe if plant diseases develop (17,31). Multiple Phytophthora spp. are known as major pathogens of nursery plants (17). As the plant trade continues to increase globally, Phytophthora spp. continue to spread into new areas and threaten nurseries, landscapes, and forest ecosystems in the United States and other countries (45). Historically, nurseries have been responsible for, and continue to provide, one of the main routes of pathogen movement and introduction of exotic plant pathogens into native ecosystems $(10,45,48,67,76)$.

One Phytophthora sp. that has gained attention for causing severe losses both in nurseries and forests is Phytophthora ramorum Werres, De Cock \& Man in't Veld (57). This pathogen has been distributed with infected plants among nurseries in the United States, providing an opportunity for this pathogen to become established in new locations. In 2004, P. ramorum-infected camellia and rhododendron plants were shipped across the United States from Oregon and California nurseries $(18,57)$. Incidents such as these have elevated concerns of $P$. ramorum spreading to other locations in the United States. This has provoked a wide range of surveys in both nurseries and forest ecosystems in an effort to detect and eradicate this organism $(2,11,31,50,57,62,70,71,77)$. As a result of these surveys, a number of Phytophthora spp. new to the United States have been discovered. This includes several newly described species $(1,13,14,20,30,31,54,55,60,62,63,71,77)$. Similar discoveries have also taken place in other countries. For example, $P$. kernoviae Brasier, Beales, and S.A. Kirk; P. austrocedrae Gresl. \& E.M. Hansen; and $P$. ramorum represent recent finds in the United Kingdom $(6,22,43)$. P. lateralis Tucker \& Milbrath was recently discovered in France and the United Kingdom infecting and killing Chamaecyparis lawsoniana (A. Murray) Parl. (21,58). Additionally, P. pinifolia Alv. Durán, Gryzenh. \& M.J. Wingf., a

Corresponding author: Y. Balci, E-mail: ybalci@umd.edu

Accepted for publication 13 August 2013.

http://dx.doi.org/10.1094/PDIS-06-13-0662-RE

(C) 2014 The American Phytopathological Society previously unknown Phytophthora sp., was discovered in Chile after causing severe outbreaks of needle disease in Pinus radiata plantations (16). Similarly, Phytophthora ramorum and several new taxa were detected on nursery crops in Spain (48). Plant trade has been the main suspect in each these instances as the pathway for introduction.

In the United States, our attention has been directed toward the detection of P. ramorum. However, other Phytophthora spp. could be introduced, including listed species of regulatory concern in the United States (68). Many of these Phytophthora spp. are projected to cause significant losses in nurseries and natural ecosystems if they are ever introduced into the United States. The objective of this study was to investigate whether the introduction of Phytophthora spp. into Maryland nurseries is occurring through shipments of incoming plant material. We also identified Phytophthora spp. that are associated with or without any disease in selected Maryland nurseries in an effort to determine the species assemblages and potential of these pathogens to spread to new locations.

\section{Materials and Methods}

Study sites. Ten ornamental nurseries in Maryland were sampled between March and August 2010, 2011, and 2012. The nurseries ranged in size and production, from nurseries of over 1,000 acres to smaller, 50-acre sites. The nurseries were sampled multiple times each year, primarily in conjunction with new shipments arriving from West Coast nurseries.

Sampling method and material. We sampled plants shipped from other states and plants that were part of the inventory of the local nursery. For incoming plant material, samples were collected within $24 \mathrm{~h}$ of arriving at the nurseries and prior to being repotted or irrigated. Plants targeted during sampling included randomly selected plants (i) that showed disease symptoms and (ii) that appeared healthy and had no noticeable disease. In addition, piles of recycled potting media were collected. To isolate Phytophthora spp. from recirculating ponds, four rhododendron leaves (Rhododendron maximum) were placed in a mash bag and deployed in recirculating ponds. Leaf baits were collected from native vegetation in West Virginia. Four leaves were placed in a mesh bag and set in recirculating ponds for 5 to 10 days. At the end of the baiting period, leaves were collected and transported back to the laboratory in a cooler.

Plant genera previously listed as high-risk hosts for $P$. ramorum, such as Rhododendron and Pieris, were the focus for this study. 
However, other plant genera were also sampled if plants expressed symptoms typical of Phytophthora infection or high-risk hosts were not present. When symptomatic plants were sampled, they were evaluated for symptoms typical of Phytophthora infection (e.g. leaf necrosis, stem cankers, and shoot blight). Samples of plant tissue containing necrotic lesions were placed in 1-gal. plastic bags and transported to the laboratory in a cooler. For asymptomatic plants, potting media was collected from the pots or root balls. We collected only the roots from bare-root plants.

In addition to surveying newly arrived plants in each nursery, blocks of existing plants were surveyed for disease symptoms and sampled as described above. Disease incidence was estimated by counting the total number of symptomatic and asymptomatic plants in each shipment or block within each nursery.

Isolation. Plant tissues sampled for Phytophthora spp. were tested using direct plating, whereas potting media and water samples were evaluated using baiting methods. Necrotic tissue samples were processed within a day of sampling. Sections taken from the edges of necrotic lesions were plated on a selective agar medium containing clarified V8 juice (cV8), pimaricin at $10 \mu \mathrm{g} / \mathrm{liter}$, ampicillin at $200 \mu \mathrm{g} / \mathrm{liter}$, rifampicin at $10 \mu \mathrm{g} / \mathrm{ml}$, pentachloronitrobenzene at $25 \mu \mathrm{g} / \mathrm{liter}$, nystatin at $50 \mu \mathrm{g} / \mathrm{liter}$, and hymexazol (PARPNH) at $50 \mu \mathrm{g} /$ liter $(2,65)$. If necrotic lesions appeared to be relatively fresh, their margins were excised, blotted dry, and placed in petri plates containing of cV8-PARPNH. Otherwise, plant tissue was washed with tap water, surface disinfested in a $0.57 \% \mathrm{NaOCl}$ solution for $2 \mathrm{~min}$, rinsed in distilled water, blotted dry, then plated on cV8-PARPNH.

To isolate Phytophthora spp. from potting media, 200 to $300 \mathrm{~g}$ of potting medium was placed in a plastic container and approximately twice the amount of distilled water was added. Any organic matter floating on the surface of the water was either removed or a layer of cheesecloth was placed on the surface of the water to prevent organic debris from coming in contact with the baits. Roots collected from bare-root plants were also baited for Phytophthora spp. by flooding cut root sections in a plastic container. For baits, leaflets of Quercus robur or young leaves of $R$. maximum were used and proved to be sensitive baits to attract a diverse assemblage of Phytophthora spp. $(2,17,37,47,50,62)$. Leaves were placed on the surface of the water and incubated for 3 to 5 days at $18^{\circ} \mathrm{C}$. Following incubation, each leaf was examined for the presence of discoloration or lesion development. With oak leaflets, discolored leaves were also microscopically examined for Phytophthora sporangia (37). Leaves with discoloration or lesions were rinsed with tap water, followed by distilled water, then blotted dry and plated on cV8-PARPNH $(2,65)$. Similarly, baits collected from recirculating ponds were rinsed and blotted dry, and 7 to 10 arbitrarily selected, water-soaked necrotic lesions were plated on cV8-PARPNH as described above.

For all isolation methods, emerging colonies of putative Phytophthora spp. were subcultured on cV8 agar. Isolates identified as Phytophthora spp. were transferred to cornmeal agar slants and maintained at 8 or $15^{\circ} \mathrm{C}$.

Isolate identification. For molecular identification, isolates were grown in potato dextrose broth (Difco) for 5 to 10 days at $22^{\circ} \mathrm{C}$. The broth was removed with a pipet and mycelia were lyophilized for $12 \mathrm{~h}$. For each isolate, approximately $0.1 \mathrm{mg}$ of lyophilized mycelium was transferred to $0.2-\mathrm{ml}$ PCR strip tubes. Genomic DNA was extracted by adding $10 \mu \mathrm{l}$ of Lyse and Go polymerase chain reaction (PCR) Reagent (Thermo Scientific Pierce) to each tube and cycling the samples at $95^{\circ} \mathrm{C}$ for $2 \mathrm{~min}$, followed by $4^{\circ} \mathrm{C}$ for $2 \mathrm{~min}$. Each cycle was repeated once. The internal transcribed spacer (ITS) region was amplified and sequenced (MCLAB) using primers ITS6 and ITS4 (75). Low-quality sequences were eliminated and the procedure was repeated with new material. Sequences were aligned and edited using Geneious Pro 5.5.6 Software (Biomatter Ltd.) and compared with known DNA sequences in the National Center for Biotechnology Information database using BLAST searches. For isolates initially identified as part of the $P$. citricola complex based on ITS sequences, additional sequencing was conducted using primers TUBUF2 and TUBUR1 (41) to delineate these isolates to the correct species.

Following molecular classification, representative isolates of each species were examined and classified morphologically to confirm their identities. Production of sporangia was induced by taking approximately $10-\mathrm{mm}^{2}$ sections from the margins of 3- to 5day-old colonies growing on $\mathrm{cV} 8$ and flooding them with nonsterile soil-extract water in $60-\mathrm{mm}$ petri dishes. Soil-extract water was prepared by mixing $500 \mathrm{ml}$ of distilled water with $250 \mathrm{~g}$ of forest soil, straining the soil extract through Miracloth (EMD Millipore), then filtering the suspension by vacuum through a Whatman number 1 filter. Cultures were kept at $22^{\circ} \mathrm{C}$ in ambient fluorescent light from the laboratory. If no sporangia formed within $24 \mathrm{~h}$, the soilextract water was discarded and replaced with fresh soil-extract water daily until sporangia were produced. Hyphal swelling production was also noted using soil-extract water. All other structures were investigated on cV8 agar cultures 1 month old or older. Asexual and sexual structures were compared using a tabular key that includes 117 species of Phytophthora (47). A more comprehensive Lucid key based on types and putative epitypes and neotypes was also used for both morphological and molecular characterization (Z. G. Abad, J. C. Bienapfl, Y. Balci, T. I. Burgess, M. D. Coffey, F. N. Martin, and S. Kang, unpublished data).

Mating type determination. Isolates of Phytophthora that did not produce any oospores (heterothallic) were paired with an A1 and A2 mating type of $P$. cinnamomi tester strains identified in previous studies (Y. Balci, unpublished). A 5-mm plug was taken from each heterothallic isolate and transferred to the edge of each of two $90-\mathrm{mm}$ petri plates. A 5-mm plug of each A1 and A2 isolate was placed opposite each isolate and the cultures were incubated at $22^{\circ} \mathrm{C}$ for approximately 2 weeks. If oogonia, antheridia, and oospores were produced, their morphological features and dimensions were noted for species description.

\section{Results}

In total, 1,523 samples were collected from 51 plant species and cultivars in 10 nurseries. The samples yielded 589 Phytophthora isolates from symptomatic plant tissue, infested potting media, and irrigation water. Among these isolates we identified 16 Phytophthora spp. (Table 1). P. citrophthora (R.E. Sm. \& E.H. Sm.) Leonian was the most frequently isolated species, followed by $P$. cinnamomi Rands and P. plurivora T. Jung \& T.I. Burgess (Table 1). Interestingly, all P. cambivora (Petri) Buisman isolates tested (18 isolates) were of the A1 mating type and all P. cinnamomi isolates (90 isolates) were of the A2 mating type. Morphological examinations of the other Phytophthora spp. corresponded with features typical for each respective species. Few isolates remained to be classified to correct species status. For example, some isolates were identified as P. citricola Sawada based on ITS sequences as well as morphology. However, additional sequencing targeting loci other than ITS was needed to classify them to species status and, thus, listed them as P. citricola complex (Table 1). Similarly, for a few isolates, a disagreement existed between the molecular and morphological classification. These isolates were listed as Phytophthora sp. (Table 2). No Phytophthora spp. of regulatory concern were isolated in our sampling, including P. ramorum.

Phytophthora spp. were frequently isolated from symptomatic plant tissue (17\% of total samples) but we found isolates representing many of the species also associated with asymptomatic plants (11\% of total samples), and they were often baited from potting media (Table 1). We found $P$. citrophthora associated with symptomatic and asymptomatic plants but it was most frequently isolated from symptomatic plants (Table 1). A similar trend was found with isolates of $P$. nicotianae Breda de Haan (Table 1). In contrast, although there were a limited number of isolates present, $P$. elongata A. Rea, Stukely \& T. Jung and $P$. taxon pgchlamydo were only isolated from symptomatic plants (Table 1).

Disease symptoms on a particular plant associated with different Phytophthora spp. usually were similar. However, P. citrophthora and all species regarded as $P$. citricola were most often found as- 
sociated with aboveground parts of the plants, causing foliar blight and tip dieback. In contrast, $P$. cinnamomi, $P$. cambivora, and $P$. nicotianae were found primarily infecting belowground parts of the plants associated with root rot, butt rot, and lesions expanding from root collar towards the stems.

Phytophthora isolates were most frequently isolated from Pieris and Rhododendron spp., followed by Buxus and Ilex (Fig. 1). The diversity of Phytophthora spp. isolated from a host or substrate was greatest from Pieris plants, with 12 of the 16 total Phytophthora spp. (Fig. 2; Table 1). Ten different Phytophthora spp. were isolated from Buxus, with P. nicotianae being the most frequent (Table 1). Eight Phytophthora spp. were isolated from Rhododendron spp. (Fig. 3), and Ilex spp. yielded seven different Phytophthora spp. (Table 1). The remaining plant species sampled yielded one or two Phytophthora spp. each.

Phytophthora isolates were also frequently baited from irrigation recirculating ponds and potting media (Fig. 1). Recirculated irrigation water yielded eight Phytophthora spp. and recycled potting media yielded seven. We isolated 13 species from media surrounding the plants (Table 1). Though Phytophthora spp. were

Table 1. Phytophthora spp. isolated from Maryland nurseries in 2010, 2011, and 2012 from symptomatic and asymptomatic ornamental plants, and baited from potting media and irrigation water

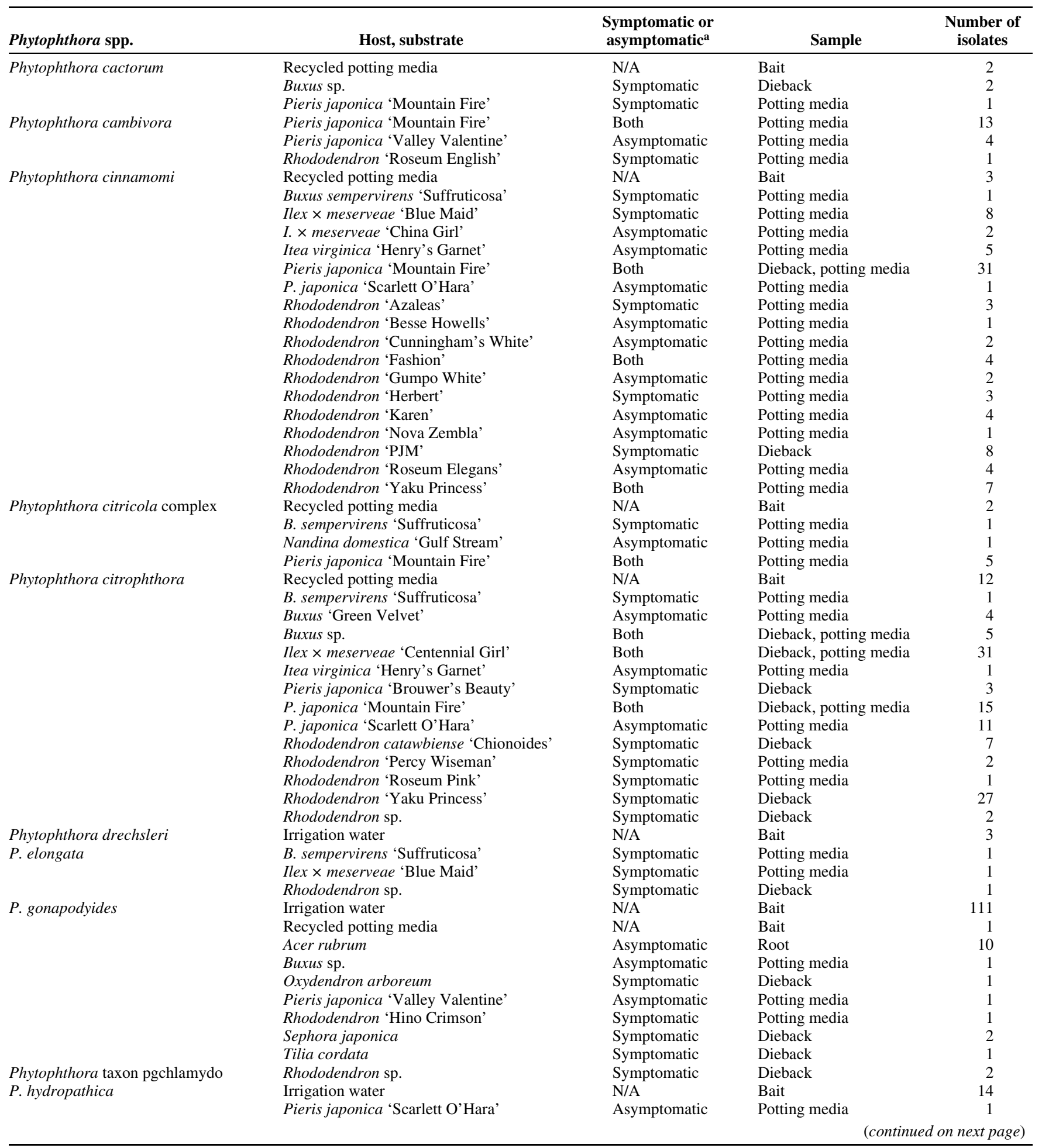

\footnotetext{
${ }^{a} \mathrm{~N} / \mathrm{A}=$ not applicable.
} 
primarily isolated from potting media, P. gonapodyides (H.E. Petersen) Buisman, $P$. hydropathica C.X. Hong \& Gallegly, and $P$. plurivora T. Jung \& T.I. Burgess were associated with both irrigation water and potting media (Table 1). The species encountered in irrigation water included $P$. drechsleri Tucker; $P$. gonapodyides; P. hydropathica; P. lacustris Brasier, Cacciola, Nechw., T. Jung \& Bakonyi; P. plurivora; P. riparia Reeser, W. Sutton \& E.M. Hansen; and $P$. syringae (Kleb.) Kleb. $P$. gonapodyides was found in association with roots from a West Coast shipment of Acer rubrum trees, as well as other symp- tomatic hosts. The only other species found in irrigation water that was also found in association with disease was $P$. plurivora (Table 1). In contrast, species in potting media were commonly found in association with disease. They included $P$. cactorum (Lebert \& Cohn) J. Schröt., P. cambivora, $P$. cinnamomi, the $P$. citricola complex, $P$. citrophthora, $P$. elongata, $P$. gonapodyides, $P$. taxon pgchlamydo, $P$. multivora P.M. Scott \& T. Jung, $P$. nicotianae, $P$. pini Leonian, and $P$. plurivora.

Nine different Phytophthora spp. were isolated from plant tissue and potting media on arrival at Maryland nurseries (Table 2). They

Table 1. (continued from preceding page)

\begin{tabular}{|c|c|c|c|c|}
\hline Phytophthora spp. & Host, substrate & $\begin{array}{l}\text { Symptomatic or } \\
\text { asymptomatic }^{\mathbf{a}}\end{array}$ & Sample & $\begin{array}{c}\text { Number of } \\
\text { isolates }\end{array}$ \\
\hline Phytophthora lacustris & Irrigation water & N/A & Bait & 1 \\
\hline \multirow[t]{10}{*}{ P. multivora } & B. sempervirens 'Suffruticosa' & Symptomatic & Potting media & 1 \\
\hline & I. $\times$ meserveae 'Blue Maid' & Symptomatic & Potting media & 2 \\
\hline & Pieris japonica 'Mountain Fire' & Both & Dieback, potting media & 16 \\
\hline & P. japonica 'Valley Valentine' & Asymptomatic & Potting media & 2 \\
\hline & Rhododendron catawbiense 'Chionoides' & Symptomatic & Dieback & 1 \\
\hline & Rhododendron 'Besse Howells' & Symptomatic & Dieback & 1 \\
\hline & Rhododendron 'Cunningham's White' & Asymptomatic & Potting media & 1 \\
\hline & Rhododendron 'Sweet 16' & Symptomatic & Potting media & 3 \\
\hline & Rhododendron 'Yaku Princess' & Asymptomatic & Potting media & 1 \\
\hline & Rhododendron sp. & Symptomatic & Dieback & 2 \\
\hline \multirow[t]{4}{*}{ Phytophthora nicotianae } & Recycled potting media & N/A & Bait & 2 \\
\hline & B. sempervirens 'Suffruticosa' & Symptomatic & Potting media & 17 \\
\hline & Buxus sp. & Both & Dieback, potting media & 25 \\
\hline & Pieris japonica 'Mountain Fire' & Asymptomatic & Potting media & 1 \\
\hline \multirow[t]{8}{*}{ Phytophthora pini } & B. sempervirens 'Suffruticosa' & Symptomatic & Potting media & 2 \\
\hline & I. × meserveae 'Blue Maid' & Asymptomatic & Potting media & 2 \\
\hline & I. $\times$ meserveae 'Centennial Girl' & Both & Potting media & 5 \\
\hline & Pieris japonica 'Mountain Fire' & Both & Potting media & 17 \\
\hline & R. catawbiense 'Chionoides' & Symptomatic & Dieback & 2 \\
\hline & Rhododendron 'Sweet 16' & Symptomatic & Potting media & 1 \\
\hline & Rhododendron 'Yaku Princess' & Asymptomatic & Potting media & 1 \\
\hline & Rhododendron sp. & Symptomatic & Dieback & 8 \\
\hline \multirow[t]{11}{*}{ Phytophthora plurivora } & Irrigation water & N/A & Bait & 3 \\
\hline & I. × meserveae 'Blue Maid' & Symptomatic & Potting media & 2 \\
\hline & I. $\times$ meserveae 'Centennial Girl' & Asymptomatic & Potting media & 6 \\
\hline & Pieris japonica 'Mountain Fire' & Both & Potting media & 30 \\
\hline & P. japonica 'Scarlett O'Hara' & Asymptomatic & Potting media & 2 \\
\hline & R. catawbiense 'Chionoides' & Symptomatic & Dieback & 1 \\
\hline & Rhododendron 'Nova Zembla' & Asymptomatic & Potting media & 1 \\
\hline & Rhododendron 'Scintillation' & Symptomatic & Dieback & 1 \\
\hline & Rhododendron 'Sweet 16' & Symptomatic & Potting media & 3 \\
\hline & Rhododendron 'Yaku Princess' & Symptomatic & Dieback & 2 \\
\hline & Rhododendron sp. & Symptomatic & Dieback & 2 \\
\hline Phytophthora riparia & Irrigation water & N/A & Bait & 3 \\
\hline P. syringae & Irrigation water & N/A & Bait & 1 \\
\hline \multirow[t]{25}{*}{ Phytophthora sp. } & Irrigation water & N/A & Bait & 1 \\
\hline & Recycled potting media & N/A & Bait & 2 \\
\hline & Acer palmatum & Asymptomatic & Potting media & 7 \\
\hline & A. rubrum & Asymptomatic & Root & 3 \\
\hline & B. sempervirens 'Suffruticosa' & Symptomatic & Potting media & 2 \\
\hline & Buxus sp. & Both & Dieback, potting media & 12 \\
\hline & Camellia sasanqua 'Yuletide' & Asymptomatic & Potting media & 1 \\
\hline & Cornus sericea “Baileyi’ & Asymptomatic & Potting media & 2 \\
\hline & Hybiscus syriacus & Symptomatic & Dieback & 1 \\
\hline & I. $\times$ meserveae 'Centennial Girl' & Asymptomatic & Potting media & 1 \\
\hline & Kalmia latifolia 'Elf' & Asymptomatic & Potting media & 1 \\
\hline & Pieris japonica 'Cavatine' & Asymptomatic & Potting media & 2 \\
\hline & P. japonica 'Mountain Fire' & Both & Dieback, potting media & 6 \\
\hline & Platanus occidentalis & Asymptomatic & Potting media & 4 \\
\hline & Quercus palustris & Asymptomatic & Potting media & 4 \\
\hline & Q. rubra & Asymptomatic & Potting media & 3 \\
\hline & R. catawbiense 'Chionoides' & Asymptomatic & Potting media & 1 \\
\hline & Rhododendron 'Anah Kruscke' & Asymptomatic & Potting media & 2 \\
\hline & Rhododendron 'Cunningham's White' & Asymptomatic & Potting media & 4 \\
\hline & Rhododendron 'Hino Crimson' & Symptomatic & Potting media & 2 \\
\hline & Rhododendron 'Karen' & Asymptomatic & Potting media & 2 \\
\hline & Rhododendron 'PJM' & Symptomatic & Potting media & 1 \\
\hline & Rhododendron 'Roseum Elegans' & Asymptomatic & Potting media & 3 \\
\hline & Rhododendron 'Roseum Pink' & Asymptomatic & Potting media & 1 \\
\hline & Rhododendron 'Scintillation' & Symptomatic & Potting media & 1 \\
\hline
\end{tabular}


were found primarily isolated from potting media collected from asymptomatic Pieris japonica and Rhododendron spp. (Fig. 4; Table 2). Other isolates were recovered from bare-root plants. Phytophthora gonapodyides and unknown Phytophthora spp. were isolated from bare roots of new shipments of Acer spp. (Table 2). However, $P$. cactorum, $P$. cambivora, $P$. cinnamomi, $P$. citrophthora, $P$. gonapodyides, $P$. multivora, $P$. pini, and $P$. plurivora were also found in association with symptomatic plants upon arrival in Maryland nurseries (Table 2).

\section{Discussion}

Phytophthora spp. are commonly associated with nursery crops in the United States, as well as in other countries. The emergence of previously unknown Phytophthora spp. in nursery crops, such as $P$. ramorum and $P$. alni Brasier \& S.A. Kirk, has increased efforts to investigate the occurrence of Phytophthora spp. in nurseries. This study is the first to evaluate nurseries in the Mid-Atlantic region of the United States for the presence of these pathogens. We identified 16 species of Phytophthora in Maryland nurseries or isolated directly from incoming plant material. Most importantly, they were frequently found in association with asymptomatic plants (e.g., potting media). This finding confirms the continued movement of Phytophthora spp. within the nursery trade and their potential spread to new environments. There is an urgent need to reevaluate current management strategies and enhance them, particularly by using approaches that take into account the critical control points in nurseries where the risk of spread by this important group of plant pathogens can be mitigated (53).

Of the 16 Phytophthora spp. identified in Maryland nurseries, $P$. citrophthora was isolated most frequently, followed by $P$. cinnamomi and the group of species previously regarded as $P$. citricola. Almost all Phytophthora spp. found in this study, P. citrophthora, $P$. cinnamomi, $P$. citricola, and $P$. nicotianae in particular have been previously reported in nurseries in the United States $(12,14,50,52,62,77)$. Some species, however, were less common. For example, $P$. cambivora is primarily known as a forest pathogen and is rarely found in association with nursery crops in the United States. It has been reported infrequently as a nursery pathogen in Oregon, California, Minnesota, and North Carolina $(52,62,71,77)$ and has also been found at low frequencies in oak forests of the eastern United States (2). Interestingly, some of the P. cambivora isolates in our study were isolated from new shipments of Pieris japonica that originated in Oregon and were only isolated from plants in a single Maryland nursery. The other plants that yielded Phytophthora cambivora were also in the same Maryland nursery and had recently arrived from the same nursery.

It was not surprising to encounter $P$. cinnamomi because it is well established in natural environments on both the West and East Coast of the United States $(2,15)$. This species was likely introduced with plant material brought by early European settlers, with reports dating back to the 1930 s, when it was isolated from rhododendron plants (74). Our findings confirm that the nursery trade

Table 2. Phytophthora spp. isolated from Maryland nurseries in 2010, 2011, and 2012 associated with newly arrived symptomatic and asymptomatic ornamental plants

\begin{tabular}{|c|c|c|c|c|}
\hline Phytophthora spp. & Host, substrate & $\begin{array}{l}\text { Symptomatic or } \\
\text { asymptomatic }\end{array}$ & Sample & $\begin{array}{c}\text { Number of } \\
\text { isolates }\end{array}$ \\
\hline Phytophthora cactorum & Pieris japonica 'Mountain Fire' & Symptomatic & Potting media & 1 \\
\hline \multirow[t]{2}{*}{ Phytophthora cambivora } & Pieris japonica 'Mountain Fire' & Asymptomatic & Potting media & 2 \\
\hline & & Symptomatic & Potting media & 2 \\
\hline \multirow[t]{3}{*}{ Phytophthora cinnamomi } & Pieris japonica 'Mountain Fire' & Asymptomatic & Potting media & 8 \\
\hline & & Symptomatic & Potting media & 13 \\
\hline & Rhododendron 'Besse Howells' & Symptomatic & Potting media & 1 \\
\hline \multirow[t]{4}{*}{ Phytophthora citrophthora } & Pieris japonica 'Mountain Fire' & Asymptomatic & Potting media & 5 \\
\hline & & Symptomatic & Potting media & 3 \\
\hline & Rhododendron catawbiense 'Chionoides' & Symptomatic & Dieback & 8 \\
\hline & Rhododendron 'Yaku Princess' & Symptomatic & Dieback & 24 \\
\hline \multirow[t]{4}{*}{ Phytophthora gonapodyides } & Acer rubrum & Asymptomatic & Root & 10 \\
\hline & Oxydendron arboreum & Symptomatic & Dieback & 1 \\
\hline & Sephora japonica & Symptomatic & Dieback & 2 \\
\hline & Tilia cordata & Symptomatic & Dieback & 1 \\
\hline \multirow[t]{5}{*}{ P. multivora } & Pieris japonica 'Mountain Fire' & Symptomatic & Potting media & 6 \\
\hline & R. catawbiense 'Chionoides' & Symptomatic & Dieback & 1 \\
\hline & Rhododendron 'Besse Howells' & Symptomatic & Dieback & 1 \\
\hline & Rhododendron 'Cunningham's White' & Asymptomatic & Potting media & 1 \\
\hline & Rhododendron 'Yaku Princess' & Asymptomatic & Potting media & 1 \\
\hline \multirow[t]{4}{*}{ Phytophthora pini } & Pieris japonica 'Mountain Fire' & Asymptomatic & Potting media & 5 \\
\hline & & Symptomatic & Potting media & 7 \\
\hline & R. catawbiense 'Chionoides' & Symptomatic & Dieback & 2 \\
\hline & Rhododendron 'Yaku Princess' & Asymptomatic & Potting media & 1 \\
\hline \multirow[t]{5}{*}{ Phytophthora plurivora } & Pieris japonica 'Mountain Fire' & Asymptomatic & Potting media & 4 \\
\hline & & Symptomatic & Potting media & 16 \\
\hline & R. catawbiense 'Chionoides' & Symptomatic & Dieback & 1 \\
\hline & Rhododendron 'Yaku Princess' & Asymptomatic & Potting media & 2 \\
\hline & Rhododendron 'Scintillation' & Symptomatic & Dieback & 1 \\
\hline \multirow[t]{14}{*}{ Phytophthora sp. } & Acer palmatum & Asymptomatic & Potting media & 7 \\
\hline & A. rubrum & Asymptomatic & Potting media & 1 \\
\hline & Buxus 'Green Velvet' & Asymptomatic & Potting media & 4 \\
\hline & Cornus sericea 'Baileyi' & Asymptomatic & Potting media & 2 \\
\hline & Kalmia latifolia 'Elf' & Asymptomatic & Potting media & 1 \\
\hline & Pieris japonica 'Cavatine' & Asymptomatic & Potting media & 2 \\
\hline & P. japonica 'Mountain Fire' & Asymptomatic & Potting media & 4 \\
\hline & Platanus occidentalis & Asymptomatic & Potting media & 4 \\
\hline & Quercus palustris & Asymptomatic & Potting media & 4 \\
\hline & Q. rubra & Asymptomatic & Potting media & 3 \\
\hline & R. catawbiense 'Chionoides' & Asymptomatic & Potting media & 1 \\
\hline & Rhododendron 'Anah Kruscke' & Asymptomatic & Potting media & 2 \\
\hline & Rhododendron 'Cunningham's White' & Asymptomatic & Potting media & 3 \\
\hline & Rhododendron 'Scintillation' & Symptomatic & Potting media & 1 \\
\hline
\end{tabular}


continues to facilitate its movement. In contrast, the most commonly encountered species in this study, $P$. citrophthora, was never reported from forest settings in the United States or in Europe. Conditions associated with the nursery environments are perhaps required for this pathogen to establish and cause disease. Similarly, $P$. nicotianae is common in nurseries but has not been found in forest ecosystems in the mid-Atlantic forests (2).

The persistence of Phytophthora spp. in the nursery environment was not linked to morphological features or sexual behavior observed in culture. For decades, our understanding of the survival and resilience of $P$. cinnamomi was primarily attributed to its thickwalled chlamydospores. However, a recent study exploring the survival mechanisms of $P$. cinnamomi in Australia's forest ecosystems indicated that hyphal aggregates in plant tissue are a more significant survival strategy. Further, oospores were routinely found in plant tissue despite the absence of the opposite mating type (e.g., inbreeding) (39). The large variety of Phytophthora spp. isolated from soilless potting media during our survey indicated similar survival mechanisms in other Phytophthora spp. Plant tissue in soilless potting media may provide additional opportunities for these organisms to survive.

We frequently isolated a species of Phytophthora previously identified as $P$. citricola. Taxonomic revisions of this group currently include six formally described taxa that are morphologically similar and closely related phylogenetically $(23,38,56,64)$. Though a commonly listed species, in previous nursery surveys, $P$. citricola isolates were never characterized to correct species status in the United States $(31,44,52,62,71,77)$. In our study, the most common species in this group was $P$. plurivora, followed by $P$. pini. The least commonly isolated species were $P$. multivora and $P$. elongata. They were associated with symptomatic plants as well as baited from infested potting media and irrigation water in four different nurseries. Currently, our knowledge regarding these four Phytophthora spp. is limited. We know little of their origin, geographic distribution, or host range. Surveys in mid-central Atlantic oak forests identified only $P$. pini and $P$. plurivora. Therefore, $P$. multivora and $P$. elongata could be of concern if introduced into the U.S. oak forest ecosystems. Both of the species were described from Eucalyptus forests of Australia $(56,64)$. Their occurrence in the U.S. nursery trade can perhaps be explained through international plant trade. However, similar to $P$. cinnamomi, these species may have been misidentified as $P$. citricola for decades and we are only now recognizing their presence.

Although we did not recover $P$. ramorum or any other Phytophthora spp. of regulatory concern in the United States, we have demonstrated the ongoing introduction of Phytophthora spp. with shipments of nursery stock. Generally, the Phytophthora spp. we isolated are known nursery pathogens; however, there is the possibility of new genotypes being introduced. This could include isolates of new races, hybrids, or new mating types with different levels of virulence, host range, and fungicide sensitivity $(15,26,28,29,34,35,40,46,55,66,69,72)$. For example, in our study, all isolates of $P$. cambivora were of mating type A1, which was also noted in a study examining $P$. cambivora populations in Oregon associated with golden chinquapin tree mortality (Chrysolepis chrysophylla) (59). The authors suspected that $P$. cambivora was introduced to Oregon due to the prevalence of the A1 mating type. P. cambivora is found sporadically in eastern oak forests but is primarily dominated by the A2 mating type $(2 ; \mathrm{M}$. McConnell and Y. Balci, unpublished). This species was also reported recently in association with root rot and stem cankers of Noble fir (Abies procera) in the Pacific Northwest (9). The consequence of this new introduction is unknown; however, this situation is of concern because $P$. cambivora is suspected to be one of the parental ancestors of the hybrid $P$. alni, which currently causes major decline of alder (Alnus spp.) in Europe $(7,33,36)$. Therefore, new introductions could lead to the development of new genotypes or hybrids, which could under-

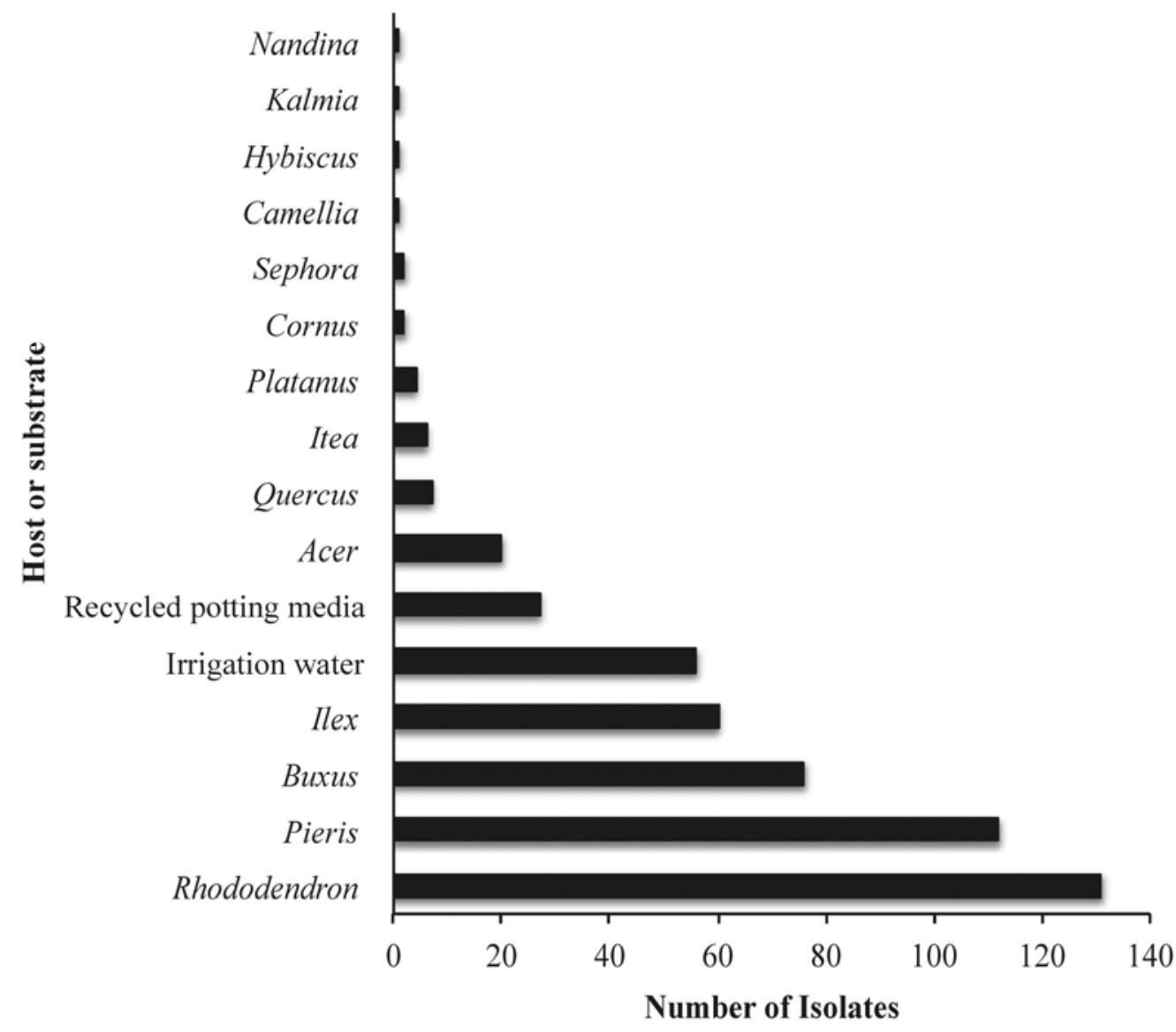

Fig. 1. Frequency of isolation of Phytophthora spp. from different hosts and substrates sampled in Maryland nurseries in 2010, 2011 , and 2012. 
mine management practices in areas where these organisms appear to be under control $(3,4,24,51,70)$.

Our surveys suggest that potting media is the most important source of introduction and spread of Phytophthora spp. to and from Maryland nurseries. Many of our Phytophthora isolates were cultured from potting media collected from asymptomatic plants as they arrived at the nurseries. We also isolated a high diversity of Phytophthora spp. from a small sample of recycled potting media. By reusing leftover potting media, the nurseries may inadvertently expose new plants to Phytophthora spp. and risk the movement of those plants off site to new locations. The nurseries are also risking the possibility of losing more plants if they are susceptible to the
Phytophthora spp. in the recycled media. Employees at one nursery we sampled indicated that they lost approximately 3,700 Viburnum plants after using recycled media to repot the plants. Minimizing or eliminating the use of recycled potting media, as well as practices that target the soil phase, should reduce the risk of movement and introduction of Phytophthora spp.

We also recovered eight Phytophthora spp. from irrigation water. Some of the species appeared to be native to stream ecosystems, such as $P$. gonapodyides, $P$. hydropathica, $P$. irrigata, and $P$. lacustris $(25,26,49 ;$ Y. Balci, unpublished). Although some of these species have been shown to be pathogenic in artificial inoculation experiments, they are rarely found associated with diseases and

\section{- Symptomatic $\square$ Asymptomatic}

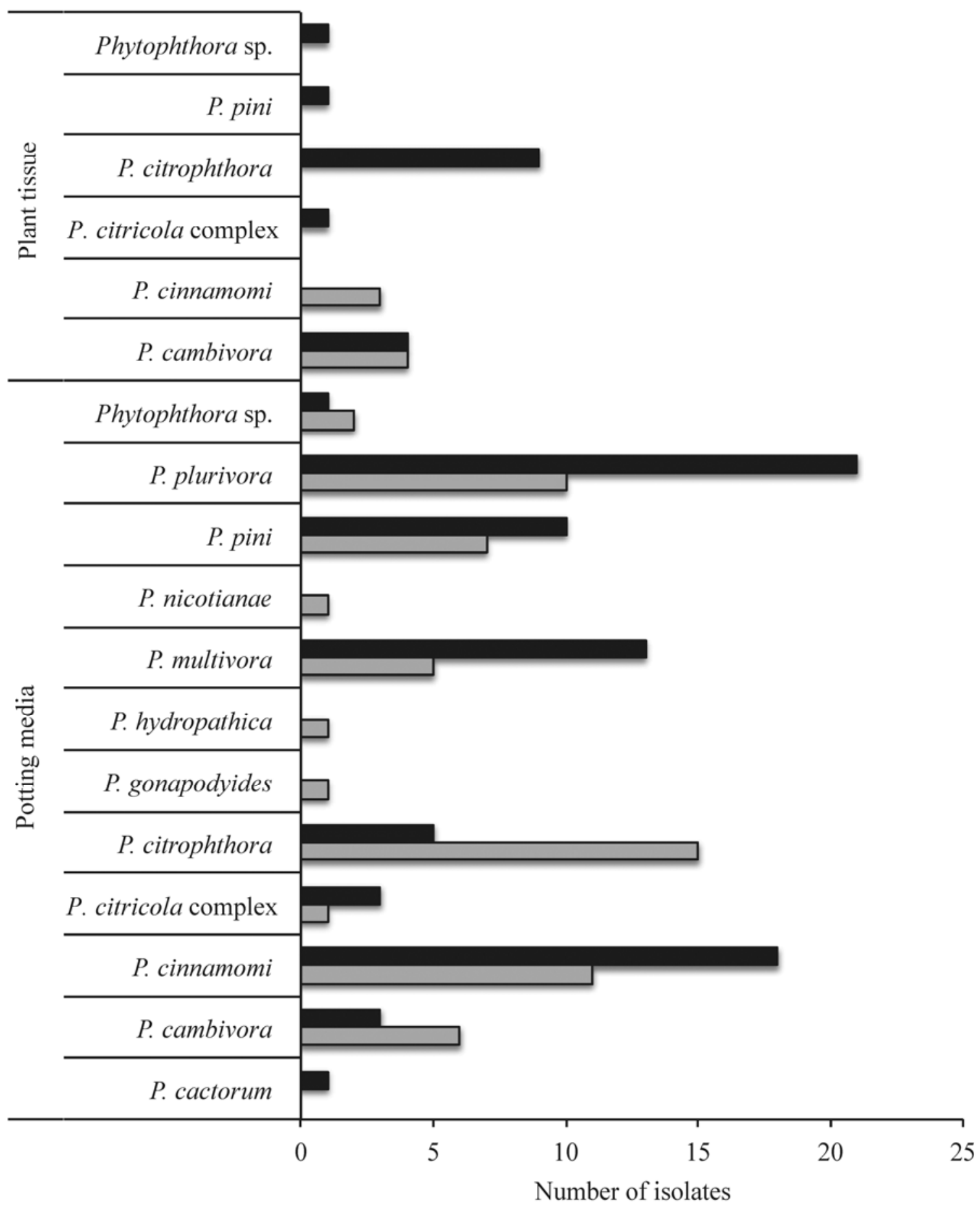

Fig. 2. Frequency of isolation of Phytophthora spp. from Pieris sp. sampled in Maryland nurseries in 2010, 2011, and 2012. 
their role as plant pathogens still remains to be determined $(24,25)$. In Maryland nurseries, these species did not cause disease levels comparable with some of the more commonly found species such as $P$. citrophthora, $P$. cinnamomi, and $P$. plurivora. Irrigation water in nurseries represents a potentially significant pathway, where new Phytophthora spp. or populations could escape into the nursery, potentially infecting additional plants, and eventually escape to new geographic locations where they could cause additional problems $(27,73)$. The opposite pathway from nurseries to the native environment is also possible with irrigation runoff. This has been observed with $P$. ramorum after it was introduced to nurseries in six states and could occur with other Phytophthora spp. we isolated in our study $(8,19,20,32,42,61)$. Although this is a concern for the possible introduction of $P$. ramorum or other Phytophthora spp. of regulatory concern, there is the risk that they could spread into the forests and cause additional disease outbreaks. In Maryland nurseries, only a few that we surveyed had irrigation water treatment systems in place, making pathogen establishment and spread among nursery plants even more likely to occur.

Our focus was to determine the movement and introduction of Phytophthora spp.; however, we also found two new fungal diseases. In one nursery, there was an outbreak on hundreds of Hibiscus syriacus 'Lavender chiffon', where plants exhibited symptoms of stem cankers and severe dieback. We determined that the causal agent was Fusarium sambucinum, which is not a known pathogen

\section{Symptomatic $\square$ Asymptomatic}

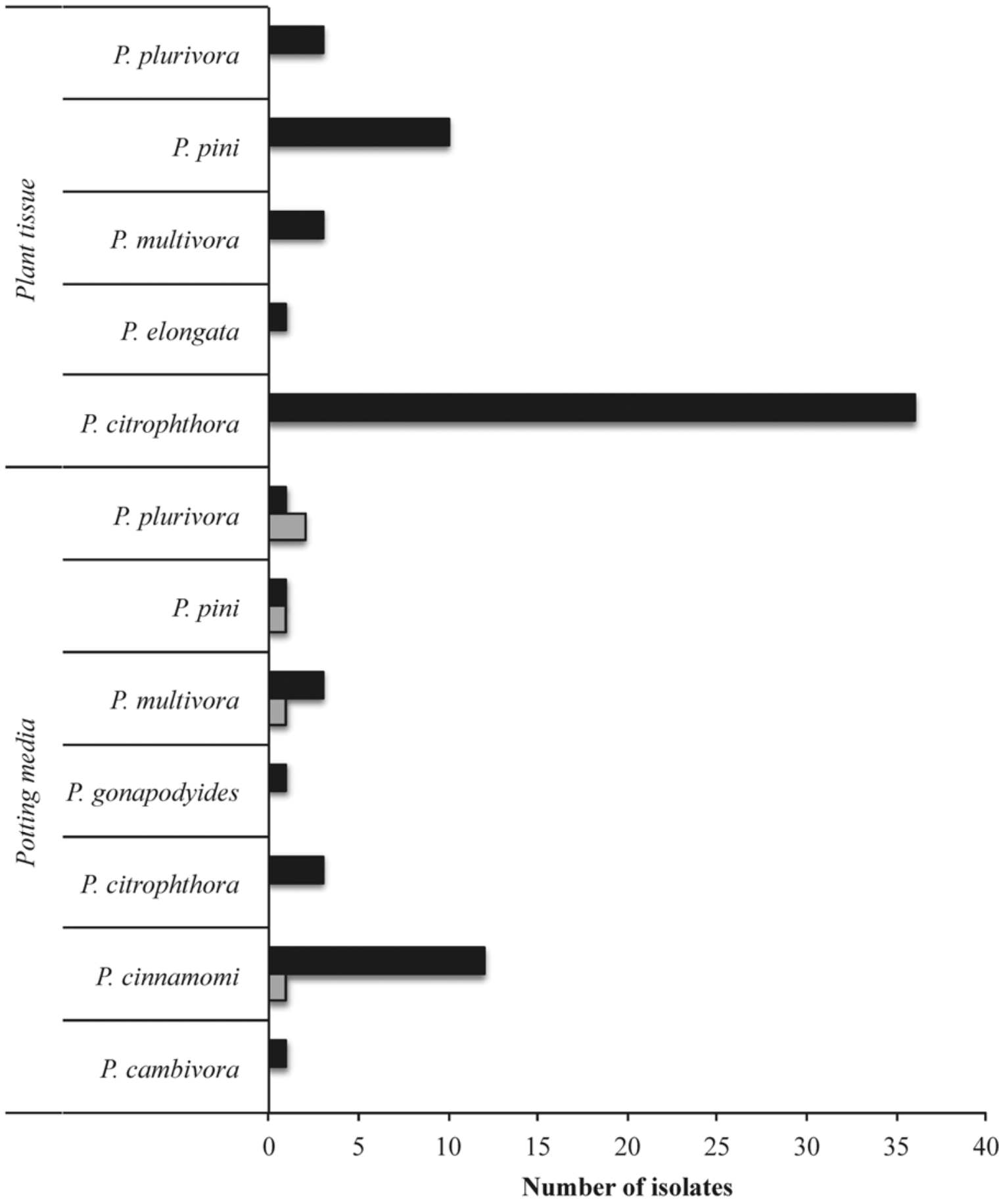

Fig. 3. Frequency of isolation of Phytophthora spp. from Rhododendron sp. sampled in Maryland nurseries in 2010, 2011, and 2012. 


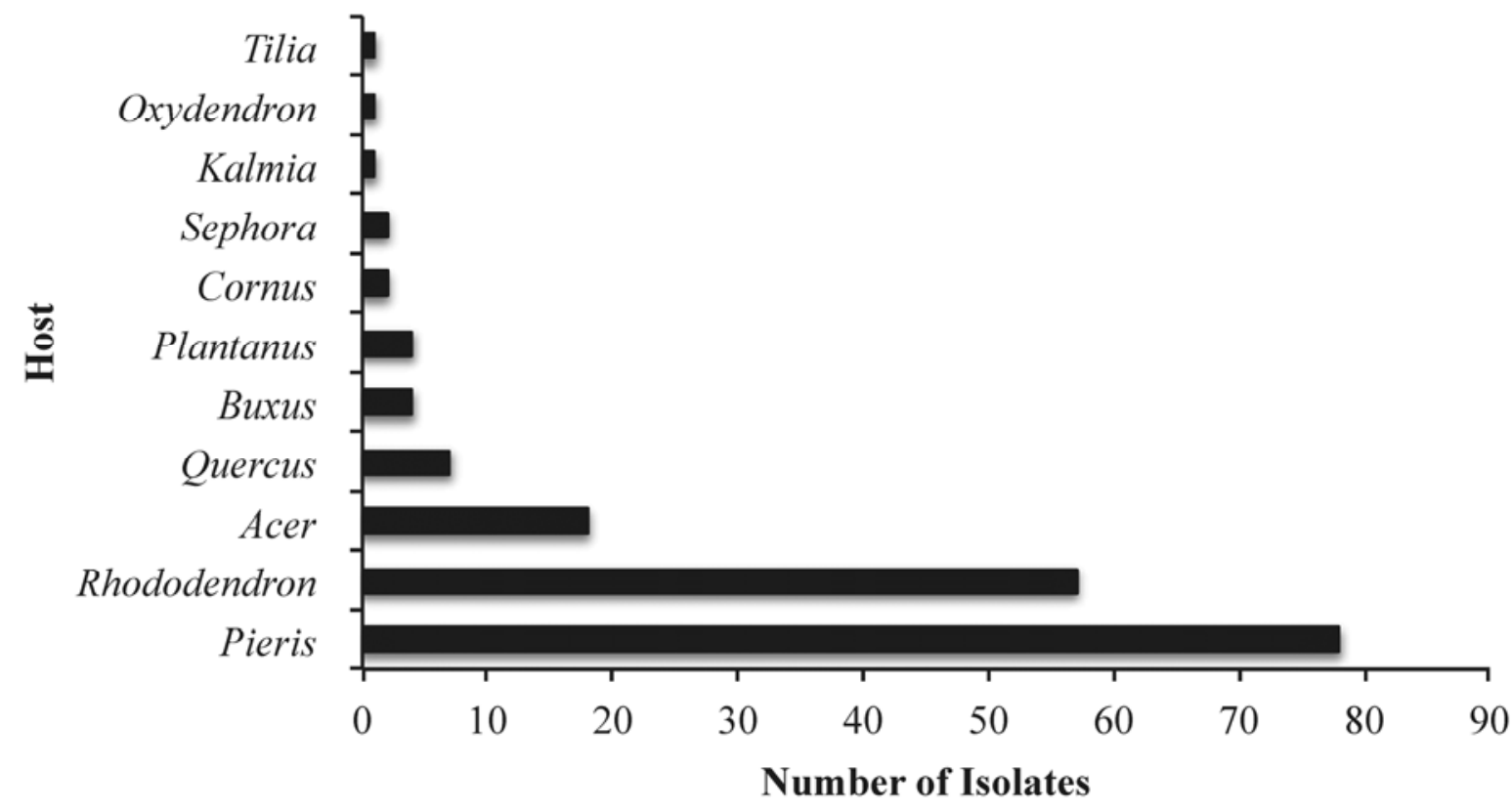

Fig. 4. Frequency of isolation of Phytophthora spp. from different hosts sampled upon arrival in Maryland nurseries in 2010, 2011, and 2012.

of $H$. syriacus (Y. Balci, unpublished). In two other nurseries, we observed thousands of Pieris japonica 'Mountain Fire' plants exhibiting symptoms of shoot dieback, stem cankers, and plant death. We determined that the causal agent was Phomopsis amygdali, which is primarily a peach and almond pathogen in the United States (5). In both cases, the infected plants arrived in shipments from West Coast nurseries and demonstrate new introductions of two fungi that were previously not known as nursery pathogens.

The presence of Phytophthora spp. in the nursery trade has been well documented (12-15,17-20,24,31,44,53,55,62,68,70,71,77). In our study, we provided direct evidences of the ongoing introduction of Phytophthora spp. into the Mid-Atlantic region of the United States. More importantly, we have verified that Phytophthora spp. can be introduced in potting media and in association with various asymptomatic hosts. Several studies have shown the potential pathways and practices that can reduce or eliminate spread of pests and pathogens (53). One very significant pathway, as shown in this study, was the potting media, which is only regulated in international U.S. plant trade. Although major efforts and regulations are in place to eliminate introduction of Phytophthora ramorum into eastern U.S. nurseries, in few locations was this quarantine pathogen detected. Clearly, current protocols used by nurseries are vulnerable and do not ensure eliminating transmission of plant pathogens into new environments. Our findings demonstrate that introduction of plant pathogens to and from Maryland nurseries is still continuing and, unless a system-based approach that uses various pest risk management measures throughout the plant production system becomes the norm in the nursery sector, they will continue to facilitate potentially very damaging pathogens.

\section{Acknowledgments}

Support for this research was provided by the USDA Animal and Plant Health Inspection Service. We thank M. Breiner, P. Di Bello, B. Ford, D. Gonçalves, V. Ho, M. McConnell, C. Quigley, K. Rane, and A. Reis for assistance with sample collection and processing; and Maryland nursery growers for their cooperation.

\section{Literature Cited}

1. Balci, Y., Balci, S., Blair, J. E., Park, S. Y., Kang, S., and Macdonald, W. L. 2008. Phytophthora quercetorum sp. nov., a novel species isolated from eastern and north-central USA oak forest soils. Mycol. Res. 112:906-916.

2. Balci, Y., Balci, S., Eggers, J., MacDonald, W. L., Juzwik, J., Long, R. P., and Gottschalk, K. W. 2007. Phytophthora spp. associated with forest soils in eastern and north-central U.S. oak ecosystems. Plant Dis. 91:705-710.

3. Bhat, R. G., and Browne, G. T. 2007. Genetic diversity in populations of Phytophthora citricola associated with horticultural crops in California.
Plant Dis. 91:1556-1563.

4. Bhat, R. G., Colowit, P. M., Tai, T. H., Aradhya, M. K., and Browne, G. T. 2006. Genetic and pathogenic variation in Phytophthora cactorum affecting fruit and nut crops in California. Plant Dis. 90:161-169.

5. Bienapfl, J. C., and Balci, Y. 2013. Phomopsis blight: a new disease of Pieris japonica caused by Phomopsis amygdali in the United States. Plant Dis. Online publication. http://dx.doi.org/10.1094/PDIS-03-13-0226-RE

6. Brasier, C. M., Beales, P. A., Kirk, S. A., Denman, S., and Rose, J. 2005 Phytophthora kernoviae sp. nov., an invasive pathogen causing bleeding stem lesions on forest trees and foliar necrosis of ornamentals in the UK. Mycol. Res. 109:853-859.

7. Brasier, C. M., Kirk, S. A., Delcan, J., Cooke, D. E. L., Jung, T., and Man in 't Veld, W. A. 2004. Phytophthora alni sp. nov. and its variants: designation of emerging heteroploid hybrid pathogens spreading on Alnus trees. Mycol. Res. 108:1172-1184.

8. Chastagner, A., Oak, S., Omdal, D., Ramsey-Kroll, A., Valachovic, Y., Lee, C., Hwang, J., Jeffers, S., and Elliott, M. 2007. Spread of $P$. ramorum from nurseries into waterways-implications for pathogen establishment in new areas. Pages 22-26 in: Proc. Fourth Meet. IUFRO Working Party S07.02.09: Phytophthoras in Forests and Natural Ecosystems. Gen. Tech. Rep. PSWGTR-211. Monterey, CA.

9. Chastagner, G. A., Hamm, P. B., and Riley, K. L. 1995. Symptoms and Phytophthora spp. associated with root rot and stem canker of Noble fir Christmas trees in the Pacific Northwest. Plant Dis. 79:290-293.

10. Coetzee, M. P. A., Wingfield, B. D., Harrington, T. C., Steimel, J., Coutinho, T. A., and Wingfield, M. J. 2001. The root rot fungus Armillaria mellea introduced into South Africa by early Dutch settlers. Mol. Ecol. 10:387-396.

11. Dart, N. L., Chastagner, G. A., Rugarber, E. F., and Riley, K. L. 2007. Recovery frequency of Phytophthora ramorum and other Phytophthora spp in the soil profile of ornamental retail nurseries. Plant Dis. 91:1419-1422.

12. Davison, E. M., Drenth, A., Kumar, S., Mack, S., Mackie, A. E., and McKirdy, S. 2006. Pathogens associated with nursery plants imported into Western Australia. Australas. Plant Pathol. 35:473-475.

13. Donahoo, R., Blomquist, C. L., Thomas, S. L., Moulton, J. K., Cooke, D. E. L., and Lamour, K. H. 2006. Phytophthora foliorum sp. nov., a new species causing leaf blight of azalea. Mycol. Res. 110:1309-1322.

14. Donahoo, R. S., and Lamour, K. H. 2008. Characterization of Phytophthora species from leaves of nursery woody ornamentals in Tennessee. HortScience 43:1833-1837.

15. Duan, C.-H., Riley, M. B., and Jeffers, S. N. 2008. Characterization of Phytophthora cinnamomi populations from ornamental plants in South Carolina, USA. Arch. Phytopathol. Pflanzenschutz 41:14-30.

16. Duran, A., Gryzenhout, M., Slippers, B., Ahumada, R., Rotella, A., Flores, F., Wingfield, B. D., and Wingfield, M. J. 2008. Phytophthora pinifolia sp. nov. associated with a serious needle disease of Pinus radiata in Chile. Plant Pathol. 57:715-727.

17. Erwin, D. C., and Ribeiro, O. K. 1996. Phytophthora Diseases Worldwide. American Phytopathological Society, St. Paul, MN.

18. Frankel, S. J. 2008. Sudden oak death and Phytophthora ramorum in the USA: a management challenge. Australas. Plant Pathol. 37:19-25.

19. Ghimire, S. R., Richardson, P. A., Kong, P., Hu, J., Lea-Cox, J. D., Ross, D. S., Moorman, G. W., and Hong, C. 2011. Distribution and diversity of Phy- 
tophthora species in nursery irrigation reservoir adopting water recycling system during winter months. J. Phytopathol. 159:713-719.

20. Ghimire, S. R., Richardson, P. A., Moorman, G. W., Lea-Cox, J. D., Ross, D. S., and Hong, C. X. 2009. An in-situ baiting bioassay for detecting Phytophthora species in irrigation runoff containment basins. Plant Pathol. 58:577-583.

21. Green, S., Brasier, C. M., Schlenzig, A., McCracken, A., MacAskill, G. A., Wilson, M., and Webber, J. F. 2013. The destructive invasive pathogen Phytophthora lateralis found on Chamaecyparis lawsoniana across the UK. For. Pathol. 43:19-28.

22. Green, S., Hendry, S. J., MacAskill, G. A., Laue, B. E., and Steele, H. 2012. Dieback and mortality of Juniperus communis in Britain associated with Phytophthora austrocedrae. New Dis. Rep. 26. Online publication. http://dx.doi.org/10.5197/j.2044-0588.2012.5026.5002

23. Hong, C., Gallegly, M. E., Richardson, P. A., and Kong, P. 2011. Phytophthora pini Leonian resurrected to distinct species status. Mycologia 103:351-360

24. Hong, C., Richardson, P. A., and Kong, P. 2008. Pathogenicity to ornamental plants of some existing species and new taxa of Phytophthora from irrigation water. Plant Dis. 92:1201-1207.

25. Hong, C. X., Gallegly, M. E., Richardson, P. A., Kong, P., and Moorman, G. W. 2008. Phytophthora irrigata, a new species isolated from irrigation reservoirs and rivers in Eastern United States of America. FEMS Microbiol. Lett. 285:203-211.

26. Hong, C. X., Gallegly, M. E., Richardson, P. A., Kong, P., Moorman, G. W., Lea-Cox, J. D., and Ross, D. S. 2010. Phytophthora hydropathica, a new pathogen identified from irrigation water, Rhododendron catawbiense and Kalmia latifolia. Plant Pathol. 59:913-923.

27. Hong, C. X., and Moorman, G. W. 2005. Plant pathogens in irrigation water: challenges and opportunities. Crit. Rev. Plant Sci. 24:189-208.

28. Hu, J. H., Hong, C. X., Stromberg, E. L., and Moorman, G. W. 2007. Effects of propamocarb hydrochloride on mycelial growth, sporulation, and infection by Phytophthora nicotianae isolates from Virginia nurseries. Plant Dis. 91:414-420.

29. Hu, J. H., Hong, C. X., Stromberg, E. L., and Moorman, G. W. 2010. Mefenoxam sensitivity in Phytophthora cinnamomi isolates. Plant Dis. $94 \cdot 39-44$

30. Hüberli, D., Lutzy, B., Voss, B., Calver, M., Ormsby, M., and Garbelotto, M. 2008. Susceptibility of New Zealand flora to Phytophthora ramorum and pathogen sporulation potential: an approach based on the precautionary principle. Australas. Plant Pathol. 37:615-625.

31. Hulvey, J., Gobena, D., Finley, L., and Lamour, K. 2010. Co-occurrence and genotypic distribution of Phytophthora species recovered from watersheds and plant nurseries of eastern Tennessee. Mycologia 102:1127-1133.

32. Hwang, J., and Benson, D. M. 2005. Identification, mefenoxam sensitivity, and compatibility type of Phytophthora spp. attacking floriculture crops in North Carolina. Plant Dis. 89:185-190.

33. Ioos, R., Andrieux, A., Marcais, B., and Frey, P. 2006. Genetic characterization of the natural hybrid species Phytophthora alni as inferred from nuclear and mitochondrial DNA analyses. Fungal Genet. Biol. 43:511-529.

34. Ireland, K. B., Huberli, D., Dell, B., Smith, I. W., Rizzo, D. M., and Hardy, G. E. S. J. 2011. Potential susceptibility of Australian native plant species to branch dieback and bole canker diseases caused by Phytophthora ramorum. Plant Pathol. 61:234-246.

35. Jackson, K. L., Yin, J., Csinos, A. S., and Pingsheng, J. 2010. Fungicidal activity of fluopicolide for suppression of Phytophthora capcisi on squash. Crop Prot. 29:1421-1427.

36. Jung, T., and Blaschke, M. 2004. Phytophthora root and collar rot of alders in Bavaria: distribution, modes of spread and possible management strategies. Plant Pathol. 53:197-208.

37. Jung, T., Blaschke, H., and Osswald, W. 2000. Involvement of soilborne Phytophthora species in Central European oak decline and the effect of site factors on the disease. Plant Pathol. 49:706-718.

38. Jung, T., and Burgess, T. I. 2009. Re-evaluation of Phytophthora citricola isolates from multiple woody hosts in Europe and North America reveals a new species, Phytophthora plurivora sp. nov. Persoonia 22:95-110.

39. Jung, T., Colquhoun, I. J., Hardy, G. E. S. J., and Woodward, S. 2013. New insights into the survival strategy of the invasive soilborne pathogen Phytophthora cinnamomi in different natural ecosystems in Western Australia. For. Pathol. Online publication. doi:10.1111/efp.12025:n/a-n/a

40. Keinath, A. P. 2007. Sensitivity of populations of Phytophthora capsici from South Carolina to mefenoxam, dimethomorph, zoxamide, and cymoxanil. Plant Dis. 91:743-748.

41. Kroon, L. P. N. M., Bakker, F. T., van den Bosch, G. B. M., Bonants, P. J. M., and Flier, W. G. 2004. Phylogenetic analysis of Phytophthora species based on mitochondrial and nuclear DNA sequences. Fungal Genet. Biol. 41:766-782.

42. Lamour, K. H., Daughtrey, M. L., Benson, D. M., Hwang, J., and Hausbeck, M. K. 2003. Etiology of Phytophthora drechsleri and P. nicotianae (=P. parasitica) disease affecting floriculture crops. Plant Dis. 87:854-858.

43. Lane, C. R., Beales, P. A., Hughes, K. J. D., Griffin, R. L., Munro, D., Brasier, C. M., and Webber, J. F. 2003. First outbreak of Phytophthora ramorum in England, on Viburnum tinus. Plant Pathol. 52:414-414.

44. Leonberger, A. J., Speers, C., Ruhl, T., Creswell, T., and Beckerman, J. L.
2013. A survey of Phytophthora spp. in Midwest nurseries, greenhouses and landscapes. Plant Dis. 97:635-640.

45. Liebhold, A. M., Brockerhoff, E. G., Garrett, L. J., Parke, J. L., and Britton, K. O. 2012. Live plant imports: the major pathway for forest and pathogen invasions of the US. Front. Ecol. Environ. 10:135-143.

46. Man in 't Veld, W. A., de Cock, A. W. A. M., and Summerbell, R. C. 2007. Natural hybrids of resident and introduced Phytophthora species proliferating on multiple new hosts. Eur. J. Plant Pathol. 117.

47. Martin, F. N., Abad, Z. G., Balci, Y., and Ivors, K. 2012. Identification an detection of Phytophthora: reviewing our progress, identifying our needs. Plant Dis. 96:1080-1103.

48. Moralejo, E., Lefort, F., Descals, E., Belbahri, L., Perez-Sierra, A. M., an Alvarez, L. A. 2009. Multiple alien Phytophthora taxa discovered on diseased ornamental plants in Spain. Plant Pathol. 58:100-110.

49. Nechwatal, J., Bakonyi, J., Cacciola, S. O., Cooke, D. E. L., Jung, T., Nagy, Z. A., Vannini, A., Vettraino, A. M., and Brasier, C. M. 2013. The morphology, behaviour and molecular phylogeny of Phytophthora taxon Salixoil and its redesignation as Phytophthora lacustris sp. nov. Plant Pathol. 62:355-369.

50. Olson, H. A., and Benson, D. M. 2011. Characterization of Phytophthora spp. on floriculture crops in North Carolina. Plant Dis. 95:1013-1020.

51. Olson, H. A., Carbone, I., and Benson, D. M. 2011. Phylogenetic history of Phytophthora cryptogea and P. drechsleri isolates from floriculture crops in North Carolina greenhouses. Phytopathology 101:1373-1384.

52. Osterbauer, N. K., Griesbach, J. A., and Hedberg, J. 2004. Surveying for and eradicating Phytophthora ramorum in agricultural commodities. Plant Health Progress. Online publication. doi:10.1094/PHP-2004-0309-02-RS

53. Parke, J. L., and Grünwald, N. J. 2012. A systems approach for management of pests and pathogens of nursery crops. Plant Dis. 96:1236-1244.

54. Parke, J. L., Grünwald, N., Lewis, C., and Fieland, V. 2009. Recovery of Phytophthora species from critical control points in horticultural nurseries. (Abstr.) Phytopathology 99:S100.

55. Perez-Sierra, A., Alvarez, L. A., Vercauteren, A., Heungens, K., and AbadCampos, P. 2011. Genetic diversity, sensitivity to phenylamide fungicides and aggressiveness of Phytophthora ramorum on Camellia, Rhododendron, and Viburnum plants in Spain. Plant Pathol. 60:1069-1176.

56. Rea, T. J., Jung, T., Burgess, T. I., Stukely, M. J. C., and Hardy, G. E. S. J. 2010. Phytophthora elongata sp. nov., a novel pathogen from the Eucalyptus marginata forest of Western Australia. Australas. Plant Pathol. 39:477491.

57. Rizzo, D. M., Garbelotto, M., and Hansen, E. A. 2005. Phytophthora ramorum: integrative research and management of an emerging pathogen in California and Oregon forests. Annu. Rev. Phytopathol. 43:309-335.

58. Robin, C., Piou, D., Feau, N., Douzon, G., Schenck, N., and Hansen, E. M 2011. Root and aerial infections of Chamaecyparis lawsoniana by Phy tophthora lateralis: a new threat for European countries. For. Pathol. 41:417-424.

59. Saavedra, A., Hansen, E. M., and Goheen, D. J. 2007. Phytophthora cambivora in Oregon and its pathogenicity to Chrysolepis chrysophylla. For Pathol. 37:409-419.

60. Saude, C., Hurtado-Gonzales, O. P., Lamour, K. H., and Hausbeck, M. K. 2008. Occurrence and characterization of a Phytophthora sp. pathogenic to asparagus (Asparagus officinalis) in Michigan. Phytopathology 98:10751083.

61. Schwingle, B. W., and Blanchette, R. A. 2008. Host range investigations of new, undescribed, and common Phytophthora spp. isolated from ornamental nurseries in Minnesota. Plant Dis. 92:642-647.

62. Schwingle, B. W., Smith, J. A., and Blanchette, R. A. 2007. Phytophthora species associated with diseased woody ornamentals in Minnesota nurseries. Plant Dis. 91:97-102.

63. Schwingle, B. W., Smith, J. A., Blanchette, R. A., Gould, S., Blanchette, B L., Pokorny, J., and Cohen, S. D. 2006. First report of dieback and leaf lesions on Rhododendron sp. caused by Phytophthora hedraiandra in the United States. Plant Dis. 90:109-109.

64. Scott, P. M., Burgess, T. I., Barber, P. A., Shearer, B. L., Stukely, M. J. Hardy, G. E., and Jung, T. 2009. Phytophthora multivora sp. nov., a new species recovered from declining Eucalyptus, Banksia, Agonis and other plant species in Western Australia. Persoonia 22:1-13.

65. Shew, H. D., and Benson, D. M. 1982. Qualitative and quantitative soil assays for Phytophthora cinnamomi. Phytopathology 72:1029-1032.

66. Silvar, C., Merino, F., and Diaz, J. 2006. Diversity of Phytophthora capsici in northwest Spain: analysis of virulence, metalaxyl response, and molecular characterization. Plant Dis. 90:1135-1142.

67. Stokstad, E. 2004. Nurseries may have shipped sudden oak death pathogen nationwide. Science 303:1959.

68. Sullivan, M., and Bulluck, R. 2010. Phytophthora Species in the Environment and Nursery Settings. New Pest Response Guidelines. USDA-APHIS PPQ Emergency and Domestic Programs, Emergency Management, Riverdale, MD.

69. Sullivan, M. J., Parks, E. J., Cubeta, M. A., Gallup, C. A., Melton, T. A., Moyer, J. W., and Shew, H. D. 2010. An assessment of the genetic diversity in a field population of Phytophthora nicotianae with a changing race structure. Plant Dis. 94:455-460.

70. Tubajika, K. M., Bulluck, R., Shiel, P. J., Scott, S. E., and Sawyer, A. J. 
2006. The occurrence of Phytophthora ramorum in nursery stock in California, Oregon, and Washington states. Plant Health Progress. Online publication. doi:10.1094/PHP-2006-031502-RS

71. Warfield, C. Y., Hwang, J., and Benson, D. M. 2008. Phytophthora blight and dieback in North Carolina nurseries during a 2003 survey. Plant Dis. 92:474-481.

72. Weiland, J. E., Nelson, A. H., and Hudler, G. W. 2009. Effects of mefenoxam, phosphonate, and paclobutrazol on in vitro characteristics of Phytophthora cactorum and P. citricola and on canker size of European beech. Plant Dis. 93:741-746.

73. Werres, S., Wagner, S., Brand, T., Kaminski, K., and Seipp, D. 2007. Survival of Phytophthora ramorum in recirculating irrigation water and subsequent infection of Rhododendron and Viburnum. Plant Dis. 91:1034-1044.
74. White, R. P. 1936. Summary of nine years experience with rhododendron wilt. Plant Dis. Rep. 20:204-207.

75. White, T. J., Bruns, T., Lee, S. B., and Taylor, J. 1990. Amplification and direct sequencing of fungal ribosomal RNA genes for phylogenetics. Pages 315-322 in: PCR Protocols: A Guide to Methods and Applications. M. A Innis, D. H. Gelfand, J. J. Sninsky, and T. J. White, eds. Academic Press, San Diego, CA.

76. Wingfield, M. J., Slippers, B., Roux, J., and Wingfield, B. D. 2001. Worldwide movement of exotic forest fungi, especially in the tropics and the southern hemisphere. BioScience 51:134-140.

77. Yakabe, L. E., Blomquist, C. L., Thomas, S. L., and MacDonald, J. D. 2009 Identification and frequency of Phytophthora species associated with foliar diseases in California ornamental nurseries. Plant Dis. 93:883-890. 